\title{
DIFFERENCES OF MANUAL NATIONAL EXAM AND COMPUTER BASED NATIONAL EXAM (UNBK) USING COMPARISON OF SCORES AND PUBLIC PERCEPTIONS
}

\author{
Nestiyanto Hadi $^{\left.a^{*}\right)}$, Dwi Kartika Susanti ${ }^{a)}$, Muhamad Rais ${ }^{a)}$ \\ a) STKIP Arrahmaniyah, Depok, Indonesia \\ ${ }^{*}$ Corresponding Author: ntaybio@gmail.com
}

Article history: received 19 August 2019; revised 31 August 2019; accepted 16 September 2019

\begin{abstract}
The government held a national exam every year as a learning evaluation tool. The general public gave many responses to the implementation of the national exam. There are people who are satisfied and there are also people who are not satisfied. The factors that cause public dissatisfaction are the leaked problem test and massive acts of cheating. The government took the initiative to change the mechanism of the national exam which originally used the computer answer sheet (manual) to be computer-based (UNBK). This study's purpose is to determine whether there are differences between the implementation of the manual and computerbased national exam. The research method used descriptive analysis based on the data of the acceptance scores of new high school (SMA) students and the questionnaires. The conclusion is there are differences between the implementation of manual and computerbased national exam. The mean value of UNBK is lower with the standard deviation value greater than the manual national exam. It can show that the scores obtained by participants is not uniform and can be an indication that the government is able to minimize the leaked problem test and cheating action. In line with the public perception that more than $60 \%$ agree that the final score of UNBK shows the results of honest and fair learning evaluation.
\end{abstract}

Keywords: national exam; UNBK; learning evaluation

\section{INTRODUCTION}

The formal education process is a teaching and learning activity organized by the government through school institutions. Every level of education has a measurable curriculum and quality competency standards [1]. The process of educational activities will be evaluated periodically learning. Evaluation of learning is carried out one of which aims to determine student understanding of the material that has been learned. Evaluation of student learning outcomes that are used today is testing in the form of Semester Exams, Grades Tests, National Standard Semester Final Exams and National Examinations (UN) [2].

The National Examination is held simultaneously by the government every year. There are several things that can be obtained from the results of the UN implementation, both for the government and students [3]. One of the benefits of the implementation of the UN for the government is as a benchmark for achieving the competency of national student graduates. The results of the UN are used as a mapping and even distribution of quality of education programs at the education unit level or at the regional level [4].

National Examination Results are useful for students to get the legalization of their competency abilities. Although in its journey, the UN score is no longer the sole determinant of student graduation. However, the UN score is still a consideration for the next level of education selection [6].

In a press conference at the Ministry of Education and Culture on April 15, 2016 [7], the Minister of Education and Culture stated that there were still reports of delays in the distribution of questions, then a shortage of questions or answer sheets, there were also in some areas that lacked question envelopes or exchanged subject labels, there were also related to the English exam on listening questions, the material on the $\mathrm{CD}$ turned out to be different from the question text. Not to mention a lot of information about the leakage of questions and answers.

One alternative taken by the government to overcome the above problems is by conducting a Computer-Based National Examination (UNBK). Hopefully, the above obstacles can be overcome properly [8]. At UNBK, questions will be distributed to each computer belonging to participants of the National Examination in each school through one server so that question security is guaranteed [9]. The implementation of the computer-based National Examination is also an effort to save the examination budget taken from the APBN or APBD. Students and parents, as well as the school, can immediately find out the results of the implementation of computer-based UN because the process of examining exam results is no longer manually and is carried out outside the area. In addition, exam participants with the UNBK model cannot cheat each other's answers in the classroom. It is hoped that the improvement of the implementation of the National Examination can have a long-term impact because it touches on fundamental aspects of the development of graduate competencies. Literacy of graduates in information technology is a basic competency requirement in the 21 st century.

The legality of the National Examination based on Law number 20 of 2003 concerning the National Education System. Article 57 paragraph (1) reads "evaluation is carried 
out in the context of controlling the quality of education nationally as a form of accountability for the administration of education to interested parties". Furthermore, article 58 paragraph (2) reads "Student evaluations, education units, and educational programs are conducted by independent institutions on a regular, comprehensive, transparent and systemic basis to assess the achievement of national education standards[10].

The computer-based National Examination or computer-based test (CBT) was first held in 2014. The implementation was carried out online, although it was only limited to Singapore Indonesia Middle School and Kuala Lumpur Indonesia Middle School (SKIL). Based on the results obtained in the 2014 UNBK trial, the 2015 UNBK pilot was conducted at Indonesian schools. The UNBK pilot program was implemented in 556 schools consisting of 42 SMP / Mts, 135 SMA / MA and 379 SMK in 29 Provinces and Overseas. The government continues to improve and expand the implementation of UNBK in 2016 and beyond.

The implementation of the pioneering computerbased National Examination or computer-based test in 2015 has several benefits. The first benefit can improve the quality, flexibility, and reliability of the National Examination. The next benefit is to expedite the process of procuring the National Examination so that the results obtained are faster and detailed to be conveyed to students, parents, and schools [11].

Implementation of the computer-based National Examination is a big hope to improve the quality of learning evaluation. This is supported by several things, namely the making of good questions, honest and credible implementation, and having an accurate level of precision related to quality, time, number and target being addressed [12]. Therefore, the results obtained by students in taking the National Examination are useful for improving the quality of continuing education.

National Examination Results in 2015 are no longer the sole determinant of student graduation. The determination of graduation is entirely carried out by the education unit. Nevertheless, the results of the National Examination are still used for the admission selection process at a higher level. At the level of secondary education the results of the National Examination are used as the basis for the National Selection for State Higher Education (SNMPTN) which is supported by report cards in semester one to five. National Examination Results are used as a determinant of student admission at the level of basic education up to junior high and junior secondary to senior secondary education. The admission process at higher levels in DKI Jakarta uses the online New Student Acceptance (PPDB) system. The use of PPDB online systems is also used in other regions with different mechanisms according to the policies of the respective regional governments. In general, PPDB online uses the value of the National Examination results as the basis for determining student acceptance at the intended school. Although there are also other considerations, such as the distance of the school from home.
The PPDB online registration flow consists of several stages. The first stage is taking and filling out the account registration form available on the website. After that prospective students submit an account registration file that will be verified by the school operator. Accounts that have been received by prospective students are immediately used to $\log$ in to the website. Prospective students can choose and register independently by selecting three schools to go based on their respective passing grades. The next stage prospective students print proof of registration and save it.

The results of the acceptance of participants' graduation can be accessed online anywhere and anytime. There are four mechanisms available for entry in PPDB online. There are achievement paths, inclusive pathways outside Jakarta's domicile lane and domicile lanes within DKI. On the domicile path in DKI divided into 3 stages, namely stage one for the public, stage two for local and stage 3 for the remaining quota that is still available. Participants who are not accepted in stage one can re-register in stage two based on the local area of residence. Acceptance of prospective students is determined based on the ranking of the National Examination results in selected schools [13].

\section{RESEARCH METHODS}

The research method used is descriptive analysis method using primary data and secondary data. Primary data were obtained from respondents consisting of students, teachers and the community with a purposive sampling technique using the form format (questionnaire). The total number of respondents was 35 people. Secondary data were obtained through the results of new student admissions online in DKI Jakarta. Data obtained from the admission of new students in 2014, 2016 and 2017. The data taken is in the form of an average value of admission into senior secondary education at 5 municipalities. Each municipality was selected 5 samples based on superior and favorite schools. Variable $\mathrm{X}$ is the value of the results of new student admissions in 2014 (before UNBK implementation) and Y variable is the value of the results of new student admissions in 2016 and 2017 (after the implementation of UNBK). Data analysis will be tested using a statistical test to find out the difference between the value of a manual National Examination and the value of a computer-based National Examination and the public's perception of the implementation of a computer-based National Examination.

\section{RESULTS AND DISCUSSION}

The research data obtained in the form of an average value of admission to high school majoring in Natural Sciences and Social Sciences at the stage of the local lane of DKI Jakarta as well as a questionnaire related to the implementation of a computer-based National Examination. Based on statistical tests on the average value of students obtained $t_{\text {count }}$ greater than $t_{\text {table }}$, both in the comparison between the scores of UN 2014 and UNBK 2016 and UN 
2014 and UNBK 2017. On the 2014 UN and 2014 UNBK values obtained a $\mathrm{t}_{\text {count }}=2.928>\mathrm{t}_{\text {table }}=2,009$ and in the 2014 and UNBK $2017 \mathrm{UN}$ values obtained a ratio of $\mathrm{t}=6.531>\mathrm{t}$ table $=2.009$. From this value, it can be decided that Ho is rejected, so there is a difference between the results of the implementation of the value of the manual National Examination and the computer-based National Examination.

Table 1. Statistical analysis of students' mean grades

\begin{tabular}{|c|c|c|c|}
\hline $\begin{array}{l}\text { Descriptiv } \\
\text { e statistic }\end{array}$ & UN 2014 & $\begin{array}{l}\text { Mean } \\
\text { Std. Dev }\end{array}$ & $\begin{array}{l}88,31 \\
4 \\
5,209\end{array}$ \\
\hline & $\begin{array}{l}\text { UNBK } \\
2016\end{array}$ & $\begin{array}{l}\text { Mean } \\
\text { Std. Dev }\end{array}$ & $\begin{array}{l}87,48 \\
6 \\
6,542\end{array}$ \\
\hline & $\begin{array}{l}\text { UNBK } \\
2017\end{array}$ & $\begin{array}{l}\text { Mean } \\
\text { Std. Dev }\end{array}$ & $\begin{array}{l}86,04 \\
4 \\
7,189\end{array}$ \\
\hline \multirow[t]{2}{*}{$\begin{array}{l}\text { Paired } \\
\text { samples } \\
\text { correlation }\end{array}$} & $\begin{array}{l}\text { UN2014 \& } \\
\text { UNBK2016 }\end{array}$ & $\begin{array}{l}\text { Correlation } \\
\text { Sig. }\end{array}$ & $\begin{array}{l}0,967 \\
0,000\end{array}$ \\
\hline & $\begin{array}{l}\text { UN2014 \& } \\
\text { UNBK2017 }\end{array}$ & $\begin{array}{l}\text { Correlation } \\
\text { Sig. }\end{array}$ & $\begin{array}{l}0,972 \\
0,000 \\
\end{array}$ \\
\hline $\begin{array}{l}\text { Paired } \\
\text { samples } \\
\text { test }\end{array}$ & $\begin{array}{l}\text { UN2014 - } \\
\text { UNBK2016 } \\
\text { UN2014-- } \\
\text { UNBK2017 }\end{array}$ & $\begin{array}{l}t \\
d f \\
\text { Sig. } \\
t \\
d f \\
\text { Sig. }\end{array}$ & $\begin{array}{l}2,928 \\
49 \\
0,005 \\
\\
6,531 \\
49 \\
0,000\end{array}$ \\
\hline
\end{tabular}

In the $2014 \mathrm{UN} \mathrm{r}$ correlation value with the 2016 UNBK obtained was 0.967 and the 2014 UN with the 2017 UNBK was 0.972. If the value of $r$ is squared then the coefficient of determination will be obtained which can indicate the ability of the UNBK implementation variable in influencing the variable changes. $5-7 \%$ is influenced by other factors. The difference in the results of the implementation of a manual with a computer-based National Examination can also be seen in the results of the calculation of the respective standard deviations. The standard deviation values in the 2014 manual UN show smaller results than the 2016 UNBK and the 2017 UNBK. The comparison of the standard deviations is 5.209: 6, 542: 7.189. Standard deviation values can be used to determine the average distribution of data. The smaller the standard deviation the more uniform the data distribution, and vice versa the greater the standard deviation the more diverse the data distribution.

Relatively small standard deviation values in the 2014 National Examination manual indicate that the average student scores obtained are uniform. Whereas in 2016 UNBK the average value of students tends to be more diverse and in 2017 UNBK is at the highest level of diversity of student scores obtained. The more uniformity of the scores obtained by students can be one of the indications that a problem leak has been obtained that has a uniform tendency with a high average.

The results of statistical analysis, the mean value in the 2014 manual National Examination was the biggest compared to the 2016 UNBK and 2017. The 2017 UNBK manual obtained a mean value of 88.314 while the 2016 UNBK was 87.49 and the 2017 UNBK was 86.04. The decrease does not necessarily conclude that the implementation of the computer-based National Examination has failed, but in fact, can show the opposite. So that the value based on the results of the analysis of respondents obtained $60 \%$ of opinions that agree if the implementation of a computer-based National Examination can reduce question leakage and cheating. This opinion is reinforced by the system implemented by the government in the administration of UNBK. The system implemented at UNBK is a semi-online based system. The mechanism of work of the system begins with the sending of question packages from the Ministry of Education and Culture server online through the network on D-1 before the UN. The next process is synchronized on the local server in the school. The distribution of questions during the next exam will be sent from the local server to students offline [14]. The test results will be sent back from the local server to the central server online (uploaded).

The mechanism applied in the UNBK apparently not only reduces question leakage but also can save time and budget. In line with the opinions of respondents amounting to $57.14 \%$ which states the implementation of UNBK is more effective and efficient than the manual National Examination and $54.29 \%$ agree if students feel helped by the existence of UNBK. In addition, $48.57 \%$ stated that the preparation of UNBK implementation was more practical compared to the manual UN. The effective and efficient implementation of UNBK can be observed in several factors of its implementation. The first factor is related to exam questions which become a crucial point in the holding of the National Examination. In the National Examination manual, exam questions get a very large portion of the budget. This includes making question scripts, copying, securing and distributing them to each region. The high involvement of human resources in the implementation of the National Exam manually can increase the vulnerability or vulnerability of leakage of questions by unscrupulous elements [15]. However, in UNBK, this can be minimized or even eliminated. That is because the UNBK exam questions are made centrally and the distribution process is done directly (real-time) through the internet network to each local server.

The second factor is related to the process of scoring exam results. In the National Examination, the assessment manual is done simultaneously centrally. The process begins with the collection of computer answer sheets at each school to the studio or local committee, then sent again to the central committee to be corrected by scanning and grading. This requires a long time until the test results can be known by the participants and the school. At UNBK, the correction and assessment process can be done easily and faster than a 
manual National Examination. That is because at UNBK there is no longer a process of collecting computer answer sheets and correction by scanning. The collection and correction process at UNBK is done automatically in accordance with the applications available online in the internet network.

Another interesting thing about the mean value in UNBK which is smaller than the manual UN turns out to be in accordance with the opinions expressed by respondents. There are $60 \%$ of respondents who expressed doubt that the UNBK score was higher than the manual UN. Nevertheless, $65.71 \%$ stated that they agree if the results of the UNBK implementation are more able to show the results of an evaluation of learning honestly and fairly. Respondents argue objectively that high scores do not necessarily indicate a good level of intelligence and intellectual maturity of students.

Respondents believe that the implementation of UNBK directly or indirectly can have an impact on the reduction in cheating activities during the exam. This can be caused because students will get different questions randomized automatically on each computer device used. In addition, students also need to increase concentration when reading questions on each computer. This is indicated by the existence of $42.86 \%$ of respondents' opinion which states that students have more difficulty concentrating on reading problems on a computer. The light-emitting factor from the monitor, the pop up browser that often appears, the client computer (the computer stops without being able to be used) simultaneously can be a concentration breaker for students when working on exam questions. Instead of wanting to cheat, students prefer to focus on the problems they face.

The dynamics in the implementation of UNBK are quite diverse. Many positive things are felt to be better than the manual National Examinations as described above. However, there were also negative things that happened during the UNBK implementation. This relates to the facilities and infrastructure of the UNBK administration. Technical problems related to supporting facilities and infrastructure of UNBK received an assessment from respondents of $57.14 \%$ which stated that students experienced technical problems related to this matter. Most respondents highlight the implementation of UNBK which consists of three waves (shifts) for each subject. They feel that the difference in time spent on the National Examination can affect the final results. Students who get session one in the morning benefit more from their fresh and prime condition compared to the final session at noon.

The division of time sessions is implemented by the government because the number of computers available at each school is still limited. The government provides several requirements for schools that will hold the UNBK. The first requirement is the availability of at least one actor and information technology (IT) engineer. The proxy is responsible for controlling the server used. The second requirement is the provision of facilities with a minimum specification of the number of clients (computers) using a ratio of 1: 40 (1 server for 40 computers). During the 2016 and 2017 UNBK, generally, one school only provided one server with 40 computers. The lack of provision of these facilities is partly due to budget constraints.

Another problem that exists in the implementation of UNBK is related to the internet network. A total of $54.29 \%$ of respondents stated that students experience these problems. That can happen on server computers and client computers. A problem with the server that often occurs is that the computer suddenly logs out simultaneously. The problem with the client is the decrease in internet speed so that the process of moving (scrolling) the page to the next problem becomes slow and quite time-consuming.

Disturbances on the client computer can also be in the form of software (hardware) and hardware (hardware). Disorders that occur in software such as viruses and hacker attacks (hackers). As for the interference with the hardware that is a power outage or a decrease in the power voltage. Related to network security and availability of electricity is a challenge in schools in remote, outermost and disadvantaged areas.

Nevertheless, the government has conducted monitoring and evaluation to resolve obstacles related to lack of facilities and infrastructure. One of them is by involving several state universities (PTN) to cooperate in the exchange of resources (sharing resources) in the implementation of UNBK. The cooperation includes training for projectors, technicians, teachers, students and the use of available computer and internet facilities. The next step is expected to be that the government can expand cooperation by involving well-accredited private universities (PTS). So that the implementation of UNBK can be better and there is equitable distribution of infrastructure in remote, outermost and backward regions

\section{CONCLUSION}

Based on the results of the study it can be concluded that there are differences in scores between the manual National Examination and the computer-based National Examination (UNBK). Differences can be observed in the results of statistical tests, the standard deviation values, and the mean. Where the mean value of the computer-based National Examination is lower than that of the manual National Examination and has a value that tends to be not uniformly marked from a larger standard deviation value. The public perception shows a positive thing about the implementation of UNBK compared to the National Examination Manual. More than $60 \%$ agree that the final grade in the UNBK implementation shows the results of honest and fair learning evaluation. The public believes that the implementation of UNBK can reduce the occurrence of leakage of questions and cheating each other. The implementation of the UNBK is also believed to be more effective and efficient based on the time of implementation as well as the budget allocated for funds compared to the manual National Exams. 
The implementation of UNBK which has been going on since 2015 turns out there are still some shortcomings in terms of providing facilities and infrastructure. The number of client computers is still limited and the provision of internet access is not yet stable and is not evenly distributed to remote areas. Therefore, the need for increased cooperation with relevant stakeholders such as tertiary and private tertiary institutions in the implementation of the UNBK. Both in terms of providing infrastructure facilities, optimizing socialization, training IT technicians, as well as the process of monitoring, monitoring and evaluating the implementation of UNBK. Cooperation with BUMN or private vendors in guaranteeing internet connection availability. In addition, the need to increase the intensity of the UNBK National Examination try-out so that students taking the exam can adapt well. Thus, it is expected that the government can improve the quality of the final score of the National Examination and increase public trust and satisfaction by more than $80 \%$. This is useful to realize the National Examination that reflects objectivity, validity, reliability, and feasibility.

\section{REFERENCES}

[1] Afriadi, D. Z., 2014. Implementasi Manajemen Ujian Nasional Sekolah Menengah Atas di Kota Mataram. Jurnal Penelitian Ilmu Pendidikan, Vol 7 No 1:41-56.

[2] Badan Standar Nasional Pendidikan. 2017. Prosedur Operasional Standar Penyelenggaraan Ujian Nasional Tahun Pelajaran 2016/2017. Jakarta.

[3] Depdiknas. 2010. Panduan Kebijakan Pemanfaatan Hasil Ujian Nasional Untuk Perbaikan Mutu Pendidikan, Jakarta: Balitbang Kemendiknas.

[4] Fatchiati, N., Dinamika ujian Akhir dari Masa ke masa, http://print.kompas.com/baca/.

[5] Fazriyah, N., 2015. Pengaruh Model Pembelajaran dan Berpikir Kritis Terhadap Hasil Belajar Ilmu Pengetahuan Alam Sekolah Dasar Kota Depok. Jurnal Pendidikan Dasar, Vol 6 No 1: 48-57.

[6] Huda, T., 2017. Pengaruh Pelaksanaan Kebijakan KTSP dan Kompetensi Guru (PAI) Terhadap Kinerja Proses Belajar Mengajar Dalam Mewujudkan Perilaku Belajar Siswa Madrasah Aliyah Negeri Kabupaten Garut. Jurnal Ilmu Pendidikan Pedagogia, Vol 15 No 1: 621-629.

[7] Kemendikbud.2017. Informasi Ujian Nasional Berbasis Komputer, https://ubk.kemdikbud.go.id/

[8] Kementerian Pendidikan dan Kebudayaan Republik Indonesia. 2010. Panduan Kebijakan Pemanfaatan Hasil Ujian Nasional Untuk Perbaikan Mutu Pendidikan. Jakarta.

[9] Kementerian Pendidikan dan Kebudayaan Republik Indonesia. 2015. Kebijakan Perubahan Ujian Nasional. Jakarta.

[10] Keputusan Kepala Dinas Pendidikan Provinsi Daerah Khusus Ibukota Jakarta Nomor 373 Tahun 2017
Tentang Petunjuk Teknis Penerimaan Peserta Didik Baru Tahun 2017/2018.

[11] Mukhlis, H. \& Koentjoro. 2015. Pelatihan Kebersyukuran untuk Menurunkan Kecemasan Menghadapi Ujian Nasional pada Siswa SMA. Gadjah Mada Journal of Professional Psychology, Vol 1 No 3: 203-215.

[12] Pakpahan, R., 2016. Model Ujian Nasional Berbasis Komputer: Manfaat dan Tantangan. Jurnal Pendidikan dan Kebudayaan, Vol 1 No 1 : 19-35.

[13] Putra, C. A., 2016. Pengaruh Strategi Berbasis Proyek Perancangan dan Kecerdasan LogikMatematika Terhadap Kompetensi Merancang Web. Jurnal Teknologi Pendidikan, Vol 18 No 2: 90-101.

[14] Rohma, F. 2013. Kecurangan Dalam Ujian Nasional di Sekolah Menengah Atas. Artikel Ilmiah Hasil Penelitian Mahasiswa. Jember: Program Studi Sosiologi Universitas Jember

[15] Zahra, R. 2015. Pengaruh Pemanfaatan Teknologi dan Informasi Pendidikan, Motivasi Kerja Kepala Sekolah dan Kinerja Kepala Sekolah Terhadap Efektivitas Pengelolaan SMP Negeri Kota Samarinda, Jurnal Ilmiah Education Management. Vol 6 No 1: 1031-1040. 